\title{
The Importance of Technical Education for the Development of Society
}

\author{
Tomášs Kozík
}

\begin{abstract}
After 1990, the Slovak Republic saw an emergence of a negative attitude towards technical education at primary schools. However, since the beginning of the 21 st century the Government has been aware of the unfavourable development of technical education in Slovakia, and according to its autumn 2012 policy statement, it considered "education, science, research and innovation, information and digitization to be essential pillars of the knowledge-based society and economy". This statement also indicated support for strengthening of education focused on natural sciences and engineering. One of its main preconditions would be innovation of educational programs at different levels of the educational system in accordance with the requirements of pedagogical practice and in line with current needs of the labour market. Therefore, it will support the education leading to the development of job skills of primary school pupils to ensure professional orientation of students, particularly at secondary vocational schools.

The importance of technical education for the overall development of children is discussed in relation to the preparation of students to study at secondary vocational schools. A successful completion of topics in the subject of Technology at primary schools (PS) is a prerequisite for an easier transition of pupils to secondary vocational schools.
\end{abstract}

Key words: education, technical education, school reform, educational standards.

\section{Introduction}

After 1990, there was a significant change of opinion regarding the social importance of technical education at primary schools in the Slovak Republic. Though seen as the aspect of the long-term stability of society and its development, the importance of technical education at primary schools was

* Tomáš Kozík, Department of Technology and Information Technologies, Constantine The Philosopher University in Nitra, Nitra, Slovakia; tkozik@ukf.sk 


\section{Acta Technologica Dubnicae \\ volume 5, 2015, issue 3}

pushed to the background. Negative attitudes towards the teaching of technical subjects could be observed among teachers as well as within school management. It was not attractive for students either. In primary education, there was a tendency to remove workshop rooms for teaching technical subjects and replace them by classrooms with computer equipment, or using the space for other purposes. Teaching technical subjects was in many cases unprofessional, and, moreover, it was even replaced by other subjects.

These negative trends culminated after 2008. The 2008/2009 school year saw the beginning of the implementation of a school reform according to which the subject under the name Technology was to be taught only in the 7th and 8th grade with the time allotment of 0.5 hours per week. Additional adjustments occurred during the school year 2011/2012. Since that time the subject has been taught only in one school year between 5th and 9th grade with just one lesson per week. At the pre-2008 primary level (ESCED 1), technical education was taught in the 4th grade as the subject titled Work Education in the scope of 1 hour per week (Pavelka, 2013).

The system of technical education in Slovakia, approved by the Ministry of Education, Science, Research and Sport of the Slovak Republic and implemented through curriculum, caused discontent in part of professional public, provoking expert discussions and various activities aimed at changing the given state of technical education.

Negative developments in technical education at primary schools at the end of the first decade of the $21^{\text {st }}$ century had the following consequences for the society at large:

- Disinterest of primary school graduates continues after the completion of primary school studies at secondary vocational schools and then at technical universities;

- Companies begin to lack qualified specialists for manufacturing, construction and services;

- Graduates leave primary schools with a minimum of knowledge in technology - being practically technically illiterate. The same situation can be applied to graduates of secondary grammar schools;

- This threatens the stability of society in terms of sustainable development.

The adverse developments in society resulting from the negation of technical education and the necessity of urgent solutions are also highlighted in the Government Manifesto of 2012, which states:

- The Government considers education, science, research and innovation, computerization and digitization to be essential pillars of the knowledgebased society and economy; 


\section{Acta Technologica Dubnicae \\ volume 5, 2015, issue 3}

- It realizes that Slovakia's competitiveness depends on the competitive people who are educated, skilled, creative and adaptable;

- The Government will create conditions for strengthening of education in fields of science and engineering;

- The Government will gradually innovate the state educational programs according to the new priorities of state education policy by current requirements of teaching experience, beginning with technical education at primary schools - bringing the content of education and training systems to current labour market needs;

- Therefore it will support the introduction of education towards the development of working skills of primary school pupils in order to ensure professional orientation of pupils, specifically to study at secondary vocational schools (Government Manifesto of the SR, 2012).

\section{The Mission and Tasks of the Man and the World of Work Subject Committee}

In 2012 the management of the State Pedagogical Institute (SPI) in Bratislava restored the operation and activities of subject committees, which shall be established as an advisory body to the Director of SPI. The mission of subject committees is to participate in the discussion of the concept, research, and professional, methodological and other tasks related to individual educational areas and subject areas of expertise at different levels, kinds and types of schools and school facilities (Principles for the establishment and operation of the central curriculum committee) (Kozík, 2013a).

In 2013 the Committee analyzed current situation in the technical education and proposed changes to address inappropriate developments in technical education in Slovakia. In the analysis, the authors' (Members of the Man and the World of Work Committee) attention was focused on the following problems:

- Why it is necessary to teach Technology;

- Technical education and school reform;

- Technical education from the perspective of EU recommendations;

- Historical development of technical education in Slovakia;

- Reasons for making changes in the Man and the World of Work educational area;

- Manifesto of the Government and Technical Education;

- Proposed action to change the status quo (Kozík et al, 2013).

\section{Why is it necessary to teach technical subjects?}

The subjects Technology and Work Education are taught at primary schools, aimed at providing pupils with knowledge and skills in the technical area. They are the subjects which give teachers space to equip pupils with the skills in a 


\section{Acta Technologica Dubnicae \\ volume 5, 2015, issue 3}

creative school environment. The subjects have integrated character. With proper teaching, they lead to the understanding of the link between theoretical subjects and technical products, found in real life. They are characterized by strong interdisciplinary bindings, connected to the history, science, biology, physics, mathematics and other areas.

The content of the technical subjects is oriented towards the practical side of the outside world, which has a significant educational impact. It allows pupils and their parents to correctly recognize their professional orientation. Through this, children can achieve a harmonious and holistic development of their personalities, to make sure that that their skills and talents can be best applicable in real life, as well as in the labour market. The technical subjects support and develop creative thinking. In the teaching of these subjects, informationcommunication technologies may be maximally utilized and applied.

As an important part of human culture, technology has always been closely connected with the creative people's work activities. Man was, is and will be the main initiator of any technological innovations and changes that ever more intensively enter the professional and private lives of adults and children as well, and thus will always influence their attitudes, values, mental and physical health and lifestyle.

Evolution is significantly influenced by technological progress, which creates technically trained and educated individuals. Applying technical knowledge in practice is a prerequisite for a successful society. It is necessary to educate creative people and technology is a medium that makes it possible. Technical education is based on the recognition that technology paves the way for the present as well as the future of human existence.

Daily life brings a lot of new information, problems, practical activities and tasks for pupils at school to communicate in an integrated form, for example as model situations. Teaching experience confirms that the practical creative activity is important for healthy and natural development of children, allowing them to be authentic and objective in learning about the outside world and giving them a good feeling, the necessary self-confidence, self-realization, new attitudes and values in relation to people, work, technology and the environment. Technical education at primary schools is the first opportunity of professional choice for children. It is a chance to become familiar with the most common tools, the basic procedures of working with different materials, with common problems of practical life and possible solutions. Technology lessons create opportunity for children to decide which activities are most interesting, so that they can focus on them in their further study and professional work. 


\section{Acta Technologica Dubnicae \\ volume 5, 2015, issue 3}

The development of thinking in preschool age is significantly affected by handling operations with different types of toys. First, there are different simple puzzles. Later a baby starts looking for more complex toys. He/she finds technical toys based on composing or decomposing activities, e.g. game of building blocks in which a child designs real objects - models corresponding to reality. When working with technical toys, handling games, children develop their senses, thinking and ability to express themselves. It involves creating a strategy and objective of the work, considering first and then taking action.

Already in kindergartens there have to be created all the conditions ensuring child's personality development in all areas. Neglect of technical education for children's development, e.g. the development of imagination and spatial orientation, in the earlier years cannot be fully repaired at later stages.

Subjects with technical orientation are the most appropriate for the development of independent and creative thinking, not only at primary, but at lower secondary level as well, therefore it is important to preserve and promote the integrity of education at all levels of education.

None of the other subjects from the lower secondary and 8-year grammar school framework curriculum lays the foundations of and develops the following:

- Technical spatial imagination;

- Technical, constructional, technological and technical creative thinking;

- Understanding of the applications of scientific knowledge in the operation of technical equipment;

- User-commercial thinking (which people often use in purchasing technical equipment and using them, e.g. in households);

- Information and habits of safe and hygienic use of technology in general;

- Manual habits and skills (for the processing of commercially available engineering materials), including skills to safely use tools and technical aids, available in large stores;

- The ability to implement cooperative and team-working teaching with an emphasis on experimental activities and implementation of projects in the field of technical products;

- Effective thinking and effective work with technical materials and equipment (saving materials and tools correctly and safely using appropriate technical equipment, environmental impact and disposal techniques, etc.).

The consequences of a destructive approach to the legislative conditions for the implementation of technical education at primary schools, which have been reflected in school practice since 1989, or, respectively, 1995, clearly show that the vast majority of current primary school graduates have significant insufficiencies with regards to the above mentioned points. 


\section{Technical education and school reform in the year 2008}

The Slovak professional public, before the adoption of the new Education Act, expected implementation of guidelines and recommendations of the European Parliament by the Ministry of Education, which would provide space to create a decent position of technical education in the education system at primary schools.

The school reform in technical education was expected to create conditions to ensure that every pupil, after completing primary school, had acquired a general technical education, which could liaise in further study and in everyday life. In our opinion, supported by the current education systems in the EU countries, the graduates of primary education should know the basic technical terms, they should understand the use and impact of technological development of the society, the relationship among different types of technology, the links between technology and other fields of life, they should understand the impact of technology on cultural, social, economic and political aspects. Graduates should be aware of the impact of technology on the environment, they should understand the role of society in the development and use of technology and they should know the relationship between technology and historical development. It is also important to understand the principles of the design process and the importance of research and development in technology. Furthermore, they should be able to independently propose, operate, maintain and evaluate technical processes and systems.

Providing the general technical education for primary school pupils in the current school reform is much more difficult and complex than in the past. Look into the content of the Man and the World of Work educational area leads to the conclusion and to the conviction that within the reform of the Slovak educational system, it has been forgotten to apply and incorporate the conclusions and recommendations contained in the documents of the European Union on key competences for lifelong education and learning, adopted by the European Parliament in November 2005, especially competence in mathematics, sciences and technology. According to the State Education Programme (SEP), technical education should be provided weekly with a half-hour time allotment in 7 th and 8 th grade. In the $5^{\text {th }}, 6^{\text {th }}$ and $9^{\text {th }}$ grade, the technical education was only taught in case the school is focused on this area in their school educational program. Past experience shows that schools are more oriented on foreign languages, computing, and regional education and less on technology. The admitted Education Act allows this trend to continue also in the future. This makes general technical education for primary school pupils remote and inaccessible. They will be able to control their computers, but they will not have a basic knowledge of materials, raw materials, will not know the working tools for 


\section{Acta Technologica Dubnicae \\ volume 5, 2015, issue 3}

working with wood, plastic, metal, will not be able to read simple technical drawing, make a product, will not be able to fix a bike, connect a simple electrical circuit, know the basic woodworking and metalworking machines and so on.

Neglect of technical education at primary schools has been going on for a longer period, especially since 1990 . The reform in the year 2008, from which it was expected that it would at least partially improve the situation, was very disappointing for the teachers of technical education at primary schools. Again the teachers of technical subjects had to complement their amount of teaching hours by teaching other subjects.

The progress clearly shows that the technical education, within this approved school reform, has a negative impact on high school and then on university education in technical field. Currently, the society has already a lack of qualified graduates in various fields of technical specialization in engineering, construction, electrical and chemical industries, either workers or university graduates. Many companies deal with this situation by accepting foreign workers or retrain their staff through educational institutions, where they need to invest substantial funds.

Currently, after various attempts, by senseless liquidation of district materials centres, the liquidation of technical, physical, but also professional and personal conditions at schools, society begins to feel the neglect of the general technical education at primary and secondary schools as a deficit in requirements of modern level secondary education and university studies in the technical field. From the school year 2008/2009 until the year 2015 the Man and the World of Work educational area (Working teaching, Technology, World of work), from the point of view of the Framework teaching plan (RUP) and elaborated goals, performance, terms and content of the SEP for ISCED1 ISCED2, is in absolute liquidation and in the worst situation in last 50 years.

Only fast and fundamental changes in the educational system, which will lead to the strengthening of the social status and quality of technical education at primary schools, can provide the perspective of maintaining and developing technical standards in Slovakia and thus the competitiveness of Slovakia in the EU (Kozík et al., 2013). 


\section{Technical education from the perspective of the EU recommendations}

The European Council has set in Lisbon in March of 2000 the main strategic objective for the European Community - to achieve the state in which the EU becomes the most competitive and the most dynamic knowledge based economy in the world, with the ability to constantly grow and to provide better jobs and greater social cohesion. It was a challenge for all EU countries, thus also for Slovakia.

This goal has initiated the preparation, establishment and approval of Educational working programme in which goals of the education and training of the population were formulated, agreed on by the Ministers of the Member States of the European Union responsible for education and training.

Within the recommendations of the EU about basic skills that should be obtained by individuals in lifelong learning, there is in the third point besides mathematics and science also explicitly mentioned - technical skills. (Kozík et al., 2013).

\section{Notes on the historical development of the technical education in Slovakia}

The development of views on the concept of content and function of subjects focusing on technology was changing in line with the overall development of a concept of elementary education.

After World War II, Czechoslovakia, as one of the countries of the Eastern bloc, began to apply the principle of polytechnic education according to the Soviet education system. Polytechnic education is characterized as "education where the starting point is practice, especially in the area of material production and technology. Its aim is to teach pupils the active knowledge of the content of the basic laws of nature and social sciences".

By adoption of the new Education Act regarding united school system, physical work was introduced into the schools in Czechoslovakia, which was organized in the form of public works, such as reparation of school gardens, help with work in agriculture and so on. The emphasis was put on creating pupils' interest in technology. Linking schools with society, science and technology acquired greater importance in this period. 


\section{Acta Technologica Dubnicae \\ volume 5, 2015, issue 3}

After 1989, the working teaching began to transform as the subject with more modern content. As a proof of this there was a new curriculum of the working teaching, which was approved by the Ministry of Education in 1995.

Content of the working teaching in 1st and 2nd year of primary school was integrated into art education. It was not the right decision, because the art education has different training and educational objectives as technical education. At the lower secondary degree, technical education content was prepared in two variants: traditional, which was to some extent similar to the previous themes; and a progressive curriculum, which largely applied requirements for the development of creative thinking at work. The progressive variant was divided into thematic units in two forms - basic and extended (advanced) curriculum.

The curriculum of technical education, which came into effect in September 1997, included three parts: technical education, garden work and family preparation. The curriculum of technical education was divided into basic and alternative one. For the alternative content, it would be better to use the term "extended" because the content of the curriculum had been predetermined and so it did not create an alternative in the full sense of the word. The basic curriculum should be fully taught at each primary school, the extended curriculum only where the teacher decided that he has the conditions for the quality teaching. Range of the basic curriculum for the technical education was 13 hours per year (Lukáčová \& Bánesz, 2007).

In 2008, the Government approved the National education program, which is the result of a reconstruction of education in Slovakia. The content of education at the primary school was divided into eight learning areas on the basis of the key competencies - each key competence is conducted in one educational area. The technical education at the primary school and at the lower secondary degree is included in the Man and the World of Work educational area. Technical education had been greatly reduced by the reform. Teaching was reduced into one lesson per week at primary level for the $4^{\text {th }}$ grade of the primary school and one lesson at lower secondary level in the $7^{\text {th }}$ and $8^{\text {th }}$ grade of school.

The subject the World of Work is focused on the basic knowledge and skills about the growing lawn, garden and ornamental plants. It has equal representation in the national curriculum Technology as a subject - in the $7^{\text {th }}$ and $8^{\text {th }}$ grade it was allocated 0.5 hours per week. The name of this subject in relation to its content was misleading. By name, the subject should provide students with the knowledge and skills oriented on the basics of labour law, employment and training, labour market issues, career information, career decision-making strategies, job search and business fundamentals. This knowledge and skills are 


\section{Acta Technologica Dubnicae \\ volume 5, 2015, issue 3}

lacking in the national curriculum. Despite that, they are an important part of primary education in the economically and culturally developed countries of Europe. For the part of pupils who finish their primary education, this subject would be the only way to get to know the problems of the labour market and their opportunity to enter it, job search methods, fields of study, kinds and types of jobs, small business opportunities etc.

In comparison of the final phases of development of technical education in the Slovak Republic with the EU countries, there are significant differences. Development in Slovakia has a regressive tendency, while in the EU the direction has developing character and pursues social requirements, a fact that does not apply to Slovakia.

In the evaluation of education in the EU we find more unifying objectives: understanding the role of science and technology in society, the balance between technology and the environment, the development of skills such as planning, implementation, evaluation, social ethical thinking, innovativeness, awareness, flexibility and business skills. The most important part of the educational content are: technology professions in industry and technology, safety procedures, ergonomics, design, construction techniques, evaluation of work results, history of technology, the ability to solve problems, evaluation strategies and the relationship between society and nature (Kozík et al., 2013). Slovak Republic in this area significantly lags behind the EU countries.

A particular problem in terms of historical development and direction of technical education at primary schools seems to be the naming of the subject. After considering and commenting on different names such as: working teaching, working activities, technical education and more, the Man and World of Work Committee recommended the name Technology, with the following justification:

- The name Technology is in line with the content of the educational area Man and world of work referred to in SEP (State Educational Program);

- The focus of technical education at primary schools is designed based on the theoretical foundations of science and engineering and it is therefore natural to use the word technology in this case;

- The subject with this name is clearly and unambiguously identifiable to the public;

- A similar approach to the naming of a technical subject can be found abroad;

- The name Technology sufficiently and accurately reflects the focus of the content of technical education at primary and lower secondary school stage, creating an unambiguous definition of the subject (Kozík et al., 2013). 
Ministry of Education, Science, Research and Sport of the Slovak Republic agreed to use the name Working Teaching for technical subjects in the $3^{\text {rd }}$ and 4th grade of primary school and the name Technology in the $5^{\text {th }}$ to $9^{\text {th }}$ grade of lower secondary education.

\section{The proposal of standards}

While drawing up the content and performance standards the proposers (members of the Man and World of Work Committee) accepted the following starting points:

- 1 teaching hour per week in 3rd and 4th grade of primary school and 1 hour per week in lower secondary level - in the $5^{\text {th }}$ to $9^{\text {th }}$ grade of primary school;

- topics in the proposal would be directed in such matter that there is a scope for the application of creativity of pupils in training as a key factor for the development of technical thinking of pupils at primary schools. Also each pupils' activity should conclude with practical outcomes;

- in the proposal to apply a sequence: idea - design (project) - solution product;

- create a balance between the theoretical basis and practical applications;

- propose the topics so that they meet present possibility of technical and material equipment at primary schools;

- focus attention on the application of ICT in teaching;

- in higher grades, include topics focused on advanced manufacturing technologies;

- in the proposal, the topics should be chosen based on the attractiveness for pupils as a way to achieve an increase in popularity of the subject;

- create conditions for the application of links among subjects;

- use clear, exact and concise expression (Kozík et al., 2013a; Kozík, 2013b).

\subsection{The proposal of educational standards at the primary level of education in the Slovak Republic}

The main objectives of primary education are to develop key competencies of pupils at a level that is achievable for them. These key concepts at the level of primary education are considered to be the following: communication ability, numeracy and literacy in science and technology, capability in the field of digital literacy, ability to learn and solve problems. Then there are the personal, social and civil competences, ability to understand the cultural context and to express themselves in the sense of the culture (Kožuchová \& Vargová, 2013).

Working Teaching at the primary level in the $3^{\text {rd }}$ and $4^{\text {th }}$ grade consists of five thematic units: Men and work, Creative use of technical materials, Fundamentals of Design, Catering and preparation of meals, Folk traditions and crafts. 


\section{Acta Technologica Dubnicae \\ volume 5, 2015, issue 3}

We consider the subject Working Teaching at primary school to be a fundamental subject for pupils in which they become familiar with the world of work and acquire basic professional orientation. The thematic unit "Man and Work" in the $3^{\text {rd }}$ grade highlights the importance of work and the importance of learning as a specific type of work. In the $4^{\text {th }}$ grade pupils become familiar with the importance and impact of creative human activity on human life and employment. In the thematic unit "Catering and Food preparation", pupils learn to understand technology through modern techniques they encounter at home. The most concentrated technical equipment in the household is found in the kitchen. Therefore, it is natural to combine kitchen equipment and technology with the problems of rational nutrition.

The content of this topic prepares pupils to become familiar with the basic health and safety rules in the kitchen, with the most common reasons of fires and accidents in the kitchen and with saving energy in the household. Young learners come to the understanding of the ideas and acquire the principles of how to purchase, to claim the goods, food storage and preparation of snacks for school break or for a trip.

In the $4^{\text {th }}$ grade, the pupils acquire the basics of preparing meals for special occasions, celebrations and preparing the invitations.

The thematic unit "Creative use of technical materials" in the $3^{\text {rd }}$ grade is designed to work with paper and textiles. In the $4^{\text {th }}$ grade pupils can get information about the production and properties of materials, especially wood. They learn teamwork on the product and they are able to discover new solutions. The thematic unit "Fundamentals of Design" is designed for the $3^{\text {rd }}$ grade. The unit focuses on technology in transport. Young learners acquire knowledge about the basic design elements of aircraft, cars, ships and lifting equipment. The models constructed from a kit or from the waste material. The part of this thematic unit is traffic education. An important tool in the education is the bike and its maintenance, care of the technical condition of the bicycle and cycling. The topic is closely related with the development of mobility and travelling.

In the $4^{\text {th }}$ grade pupils become familiar with electricity through the historical and modern communication tools, such as mobile phones, laptops, tablets and so on.

The thematic unit "Folk traditions and crafts" focuses attention of teachers and young learners on the manufacture of products related to folk traditions. We expect that this thematic unit will be very popular among teachers and pupils. (Kožuchová \& Vargová, 2013). 


\subsection{Proposals of educational standards in lower secondary education in the Slovak Republic}

In the proposed content and performance standards for $5^{\text {th }}$ to $9^{\text {th }}$ grade, the authors keep the principle that each thematic unit should be directed at practical activities of pupils.

Working Teaching in the $5^{\text {th }}$ grade consists of five thematic units: Rules of school technical classrooms, Man and technology, Man and manufacture, Utility items and gifts, Choice of profession and labour market.

The content of the first thematic unit is focused on the health and safety rules in the school laboratories. A part of this topic are the rules in the workplace, the procedure how work is organized in laboratories, appropriate clothes, protective equipment and hygiene.

The thematic unit "Man and Technology" addresses the issue of finding an answer to man's relationship to nature and technology. The answers for the pupils should be able to justify the need and importance of technology in human life and society.

The third thematic unit "Man and manufacture" deals with selected production of technology processing of natural materials and the production of useful products. This unit builds on thematic unit "Folk traditions and crafts" taught in the $3^{\text {rd }}$ and $4^{\text {th }}$ grade at primary school. The pupils become familiar with the working tools, instruments and their use in the manufacturing of products from natural materials in accordance with established procedures.

Thematic unit "Utility items and gifts" has a direct link to the first degree of primary school. The purpose of the theme is the promotion of pupils' creative activity by the creation of utility items or gifts. Pupils make gifts and learn to express the idea of making the product of simple graphical design, but also learn to choose their own progress and use the right tools. What we also consider important is to acquire a sense of usefulness, self-realization and experience, which may help them decide on their future career choices.

It is suitable that next thematic unit is "The choice of profession and the labour market". By age 10 to 11 , we consider it appropriate to start preparing the children for choice of their future profession with respect to the application in the labour market. Pupils will learn how to find information about jobs and job opportunities on the Internet (Lukáčová, 2013).

The $6^{\text {th }}$ grade is thematically focused on the following units: Man and Technology, Graphic communication in technology, Technical materials and 


\section{Acta Technologica Dubnicae \\ volume 5, 2015, issue 3}

processing technology, Electricity and electrical circuitry, Simple machines and mechanisms, and Work, occupation and employment.

In the first thematic unit, pupils gather knowledge about the process of the product creation throughout a cycle from an idea to implementation and to disposal of the product or waste. Pupils learn to explain the difference between invention, patent and discovery.

Pupils are taught the basis for the creation of technical documentation in the second thematic unit. They learn to view a single object when viewed from the front view or when shown the dimensions.

Properties of materials, technologies and suitable tools and instruments are contained in the third thematic unit. The result of the practical work of pupils in this case is a product formed by the combination of different materials.

Thematic unit "Electricity and electrical circuits" consists of two parts. The first part is about the production and distribution of electricity from the power source to the consumer. In the second part, named electrical circuits, pupils can create simple electrical circuits by using model kits.

In the fifth thematic unit, pupils gather knowledge about the simple machines and gears in mechanism using kits.

Thematic unit titled "Work, occupation and employment" is focused on information on occupations and professions so that this information could be used in the future when choosing high school (Lukáčová, 2013).

For the $7^{\text {th }}$ grade, for the subject Technology, educational content of thematic units has been designed: Graphic communication in technology, Technical materials and their processing, Tools and equipment at home and Work and the law.

For the $8^{\text {th }}$ grade, there are these thematic areas: Electrical household tools, Technical electronics, Technical production, Study preconditions for choosing the career.

For the $9^{\text {th }}$ grade following thematic areas have been designed: Residential installation, Materials processing, Creative activities, Secondary schools and courses for the labour market.

The content of individual thematic units is designed in such a way as to teach pupils practical skills which can help acquire the habits of creative thinking. The 


\section{Acta Technologica Dubnicae \\ volume 5, 2015, issue 3}

role and objectives of the technical subject in solving practical tasks are the increase of their interest in the technical work and technical professions. The further studies were focused on vocational schools and technical courses at universities.

Thematic units in $7^{\text {th }}$ to $9^{\text {th }}$ grade are built in such a way that pupils expand and consolidate the knowledge and skills acquired in the 5th and 6th grade. At the same time, they acquire new knowledge and information about individual thematic units.

The thematic unit "Tools and equipment" in $7^{\text {th }}$ grade teaches pupils about machines and equipment used at home, and, depending on their propulsion, describe their operation and use. They can identify the dangers of machines and equipment and search the Internet for instructions for their operation and maintenance.

In the thematic group "Work and the law", which is included in the curriculum of the $7^{\text {th }}$ grade, pupils learn about the importance of concepts related to work. They are able to explain roles of Office of Labour and what is the content and function of the Labour Code. They learn to explain the terms the price of labour, employment, unemployment, etc.

They learn about the work abroad and the risk of such work. Pupils learn to know the basic rights and obligations of workers and become familiar with services and institutions active in the labour market.

In the $8^{\text {th }}$ grade, in the thematic unit "Technical Electronics", pupils learn to understand the construction of microelectronic components in an electrical circuit, and their function in various practical applications (diodes, transistors, integrated circuits, sensors and other components and wiring). They can describe the principles of signal transmission telecommunication equipment.

In the $8^{\text {th }}$ grade, in the thematic unit "Study preconditions for choosing the career", learners are prepared for the choice of their future professional direction. Pupils are lead to the right decision about their future profession by justifying their decisions when choosing a future profession, discussing their personal and academic abilities to succeed in the chosen field and the need for lifelong learning.

Building on practical knowledge on production technologies obtained in the previous grades and from their own life experience, learners can further enhance their new knowledge and skills in the thematic unit "Creative activity". 


\section{Acta Technologica Dubnicae \\ volume 5, 2015, issue 3}

In this thematic unit, pupils design a process of creation of the product depending on the range of materials and technologies available at schools.

The final thematic unit of 9th grade, titled "Secondary schools and courses", brings pupils more information about the topic, especially focused on secondary schools with technical studies. They learn to search for the references for graduates of the individual fields of study on the Internet (Ďuriš, 2013).

In 2014, the draft of the content of Technology at lower secondary level has been supplemented by thematic area called Household Economics.

After the editing of the educational standard, the subject Technology is divided into two thematic areas: Technology and Household Economics. Each is subdivided into different thematic units. The emphasis is on thematic area Technology. The school is required to teach the topics from the thematic area of Technology for at least two thirds of the total compulsory school subject time allocation in each school year, and no more than one third of the total compulsory school subject time allocation in the school year should be allocated to the thematic area Household Economics, according to the schools' materialtechnical and personnel conditions.

Household Economics thematic area consists of the following thematic units: Planning and housekeeping, World of work, Housework and household maintenance, Food preparation and nutrition, Handicrafts, Family preparation, Cultivation and breeding work (www.minedu.sk).

\section{Technical education at primary school as an important part of preparing pupils for study at the Secondary Vocational Technical School}

Economic development of the countries currently dictates a change of society's priorities. In economic policy, the priority of the development is nowadays an area of qualitative development instead of quantitative development. Such a shift in economic priorities can be applied successfully only with the support of the educational system that can respond appropriately to the innovative demands of the national economy and society.

Despite the fact that the Slovak society has for a long time declared the need for rapid and qualitative changes in education and the restructuring of the educational system, which is expected to ensure routing of the progress of education in Slovakia in accordance with the developed countries, however, the rate and the method of implementation is questionable. Adjustment of the educational system in the Slovak Republic after 1990 has not brought a desirable output. Draft amendments were not sufficiently prepared, scientifically 
substantiated and justified. Direction of financial flows for support was also not always optimal.

It is not surprising that the technical education in Slovakia finds itself in the liquidation status at the end of the first decade of the $21^{\text {st }}$ century. Therefore, laymen and also a part of professionals are not sufficiently aware, maybe because of lack of information or under the influence of the media, of the significance and importance of technical education of the population on economic growth and development of human personality, their aspirations and needs (Kozík et al, 2013).

\subsection{Technology is an important part of the everyday life of man in society}

Although not each of us is directly involved in production of technologies and production of technical products and equipment, everyday interaction with technology is unavoidable, whether as a consumer or user. This implies a clear conclusion that every human should be ready for the interaction with technology.

Therefore, we hold an opinion that technical education should become part of general education of each person and should start from an early age - at primary school. Primary schools should become the place where the young start to become aware and to perceive the world of technology which will accompany them in their future lives.

\subsection{The role of the primary school in technical preparation of young generation}

Primary school is not only a place where the children gather knowledge, but also the environment which forms their attitude and interest in studying at secondary vocational schools. Even without more detailed research, we can say that in society there is a change in the ratio of primary school pupils who are manually and technically skilled, in favour of those who have no experience with craft works and who have never even come into personal contact with them.

Pupils who finish the primary school in Slovakia have the opportunity to choose from a wide range of secondary vocational schools. The offer of technical education in the Slovak Republic is sufficiently wide and flexible and is able to take much more candidates than what is currently in demand.

Choice of secondary vocational technical school is eliminated for potential applicant by various factors, such as: geographical location, social situation of families, social demand and the attractiveness of the field of study or school, etc. The factors mentioned above narrow the candidate's decision possibilities when choosing a school. Especially for economically weaker applicants, the basic 


\section{Acta Technologica Dubnicae \\ volume 5, 2015, issue 3}

criterion in choosing on the basis of the place of residence and the perspective of its future position in the job. Primary schools have educational advisors who are familiar with their students interested in studying at a secondary school with general education or with a particular focus on the technology. These advisors should be able to choose, in cooperation with parents and children, the proper secondary school that suits the child's abilities and interest. Coordination of the technical content of primary education with vocational subjects (mainly practical) with secondary vocational school after 1990 in the Slovak education system was not strictly enforced. Nevertheless, in this period there was not a situation where the knowledge and skills of primary school graduates who have completed a full technology education of at primary schools would be insufficient and pupils would not be prepared to study at vocational schools.

The curriculum of technical education in the Slovak Republic implemented in the education system since 1997, with certain restrictions until 2008 (a year of the reform of the education system in Slovakia), was designed to allow pupils easy transition from the level of general education at primary school to the level of specialized education, specific to that subject at vocational school and at the same time create sufficient space for alternatives.

Nevertheless, the model of technical education in Slovakia in 2008 was not used enough at primary schools to prepare pupils for a specific future profession in a technical discipline. Its implementation was left to the decision of primary school, especially in its possibilities.

Although the education system allowed for enhanced teaching of technical subjects at primary schools, it was more a rarity than a rule. Children with relationship towards technology since childhood, which connects their future to the craft, were usually not supported at primary schools.

In recent years, the choice of high schools has shown that interest in high schools on the part of parents and children was not based on examination. In this situation and with decreasing population, secondary vocational schools also accept students with low levels of knowledge, records, but also a significant lack of personal discipline, which has a significant impact on the quality of education at the secondary vocational schools and also on knowledge and skill level of students.

Requirements of currently expanding automotive industry in the Slovak Republic and also other fields demand just the opposite, knowledge and work discipline of its employees. 


\section{Acta Technologica Dubnicae \\ volume 5, 2015, issue 3}

In this regard there is a growing importance of quality of education process at primary schools. Secondary schools create an extension of education, which should take place to effectively evaluate the general knowledge and attitudes of students acquired at primary schools.

One of the main topics is a direct relevance of the interests of primary school pupils in studying at secondary vocational schools. The question is to what extent primary school graduates are prepared to study successfully at a vocational school.

Finding an answer to this question is not easy due its complexity. Each school, including primary schools, has its own characteristics, which affect the final result of learning.

Technical education is a subject that provides plenty of scope for developing interdisciplinary relations with other subjects at primary schools and not excluding the non-technical subjects. Nevertheless, technical education, in its theoretical foundation, is based mainly on the science subjects of physics, chemistry, mathematics, biology, and these foundations transform into practical actions and skills of pupils. Students gradually perceive and connect natural phenomena with technical solutions and their use in accordance with the protection of nature and the environment. This will make them gain the ability of technical thinking. To what extent depends on the quality of the learning process. The final teaching result will mainly depend on the quality and creativity of the teacher - how he/she can create with students the technical products and lead them to the creative technical thinking. Accomplishments of students in technical education, that is, solving specific technical problems, although often very simple, create their deeper interest basis and relationship with technology, which influence the students' decision about their future professional orientation. According to the curriculum of the subject Technical Education in force until 2008, when teaching at the appropriate level and with teacher paying attention to students and not neglecting the practical application of theoretical knowledge, the student is able to independently produce a functional model and perceive the proper operation of technical equipment at home but also outside the home, in real life (Blažej, 2005).

Graduate of primary school prepared in such a way can continue on further studies at vocational school of engineering or electrical engineering or a related specialization, since at the beginning of studies in technical subjects he/she will meet with known concepts, which largely facilitates the transition between primary school and secondary vocational schools. 


\section{Technical design and creativity - the fundamentals of technical education}

One of the possible strategies for achieving the aim of increasing interest of pupils in learning is using of creative thinking in teaching of Technology.

Nowadays, not only in the Slovak Republic, the trend in the educational approach where information is mediated and pupils learn the facts continues. This way of teaching of technology cannot meet the requirements even for the present nor for future at primary schools. Pupils in this system of teaching are not able to formulate their own ideas, produce unconventional ideas and there is a risk that they will not be able to solve problems independently because their courage to find new solutions was not developed during school education, but rather repressed. We support the opinion that when teachers of technical subjects focus their attention on informative, interpretative approach of intermediation of the curriculum, technical subject will continue to have educative character (Turek, 2011) and will not raise interest of primary school pupils in technology studies. We agree with this opinion because teaching based on facts loads memory and does not teach the pupil to use creative thinking approaches (Kozík \& Handlovská, 2011a).

For this reason, technical education at Slovak primary schools under the current educational conditions should have its curriculum innovated by using different activating and engaging teaching strategies. This is to be understood as a problem, project or experiential teaching that supports their opinion, learning to take a position and supports the autonomy of pupils in the decision making. They should acquire these skills at primary school; certainly it becomes beneficial for them in their personal lives and in future occupations (Kozík \& Handlovská, 2011b).

For positive educational outcome, it is important that teachers should have responsibility, supported by decision-makers in education, school leaders and parents of children, in introducing progressive strategies in education. If this is not possible, teachers will feel the social lack of appreciation of their work and it will not be easy to make the necessary changes in the strategy of teaching and to make the desired change in the interest of students in learning Technology. Currently, teachers of Technology must deal with material and technical training instructions (Handlovská, 2011; Kozík \& Handlovská, 2011a, b). 


\section{Acta Technologica Dubnicae \\ volume 5, 2015, issue 3}

One way how to attract the interest of students in this subject is mediating curriculum to students through acquired experience in everyday life. Everything that the teacher teaches is needed to relate to the pupils' experience. The teacher should emphasize the relevance of the curriculum, its originality, and use of teaching methods and resources that support pupils' learning experience.

Methods of creative thinking acquisition can be achieved by creative project ideas by students, directly involved in the process of learning and giving teachers the opportunity to mediate theoretical knowledge and deeper understanding in an amusing way.

Development of creative thinking acquisition methods encouraging communication, cooperation, teaching students to use acquired knowledge in original way is needed. It provides individuals with possibility to apply their own opinions and ideas in teaching. Students are trained in concentration, commitment and learning to discuss. Furthermore, the use of these methods results in the willingness of students to solve tasks, encourages originality of their thinking and curiosity. Developing technical creativity on the lower level of primary schools can also increase the interest of children in studying technology and later to work in technical fields (Kozík \& Handlovská, 2011a).

The ability to solve problems creatively is a capability that is necessary for life and work experience. Human beings are characterized by creativity through all life. Each modern educational system should be designed in such a way that it creates space for improvement of individuals in the technical education and allows them to carry out their hobbies through school education (Kozík \& Handlovská, 2011a).

\section{Conclusion}

School teachers and professionals believe that the adoption of the proposed concept of technical education at primary schools in the Slovak Republic and applying of innovative content of educational standards starting with the school year 2015/2016 will present the beginning of a long-term conceptual development of a system of technical education not only at primary schools but also at secondary schools and universities.

Return to teaching Technical education at primary schools at the quality level required before 2008 can significantly contribute to the fact that the Slovak Republic will continue to be the country with advanced industry and high technical level with generation of active creative potential. 


\section{Acta Technologica Dubnicae \\ volume 5, 2015, issue 3}

Learning to utilize creativity is not easy. Training of creative thinking is a longterm issue that requires an encouraging environment and professional approach. The application of creative elements in technical education is the way how to achieve an increase of students' interest in studying technical subjects and disciplines.

All the basics, whether theoretical or practical, as we have shown by comparing the curriculum of vocational subjects in the first year of secondary vocational schools (in some cases even in higher grades), are acquired by students at primary schools in the subject of Technical Education, which leads to fulfilment of the role and the importance of technical primary education. The curriculum is only part of the learning process to achieve technological literacy and positive attitude of students towards technology and their subsequent decision to proceed further in technical education at the secondary specialized schools and later at universities.

After 1990, the Slovak primary schools, given the development in the society, were not directed to support technical education at primary schools. The result of this situation was the approach to technological education at the end of the first decade of the 21 st century where underestimation of the necessity of technical education for the development of society and its economic growth caused that the technical education at primary schools in the Slovak Republic was on the verge of extinction.

We believe that a return to the teaching of technical education at primary schools in the required quality at least to the same extent as before 2008 can make a significant contribution to enabling the Slovak Republic to remain a country with advanced industry and high technical level of production characterized by active and creative technical potential. The Ministry of Education, Science, Research and Sport of the Slovak Republic made a decision to upgrade the content and scope of technical education at primary schools for the school year 2015-2016. In accordance with the decision, technical training will be conducted in the subject called Technology in $5^{\text {th }}$ to $9^{\text {th }}$ grade of primary schools in the scope of 1 hour per week and for $3^{\text {rd }}$ and $4^{\text {th }}$ grade titled Working Teaching in the scope of 1 hour per week (www.statpedu.sk, 2015). This decision is a fundamental step and it has created conditions to make positive changes in the quality of technical education in Slovakia. The focus of the themes is very close to the technical education before the year 2008.

The success of this undeniably correct decision will depend on how attention will be paid to technical subjects by the Ministry of Education, Science, Research and Sport of the Slovak Republic, school managements, teachers and the children's parents. 


\section{Acta Technologica Dubnicae \\ volume 5, 2015, issue 3}

With the support of the Ministry of Education, Science, Research and Sport of the Slovak Republic, it will be necessary that the primary schools at first return illegally cancelled classrooms for practical activities (workshops). Based on this, a functioning system for supply of equipment for the subject will be created. That subject is to be taught by qualified teachers of technical education. It is necessary that Ministry of Education, Science, Research and Sport of the Slovak Republic, in close cooperation with the universities' scientific departments, prepares future teachers and that teacher training centres elaborate and implement a system of lifelong learning of teachers of technical vocational subjects. It will be important that the State Pedagogical Institute (SPI) of the Slovak Republic, in close cooperation with professionals from public, university, and teacher sphere prepare and constantly address innovation in the curriculum. All this should be in accordance with the latest knowledge of educational science, development, manufacturing technologies, IT technologies and requirements of practice, with the results of the solutions promptly applied in the educational system.

\section{Acknowledgment}

This work was supported by the grant from the Cultural and Educational Grant Agency of the Ministry of Education of the Slovak Republic under the project KEGA No. 015PU/2013: Methodology for implementation of interactive boards in training to competences in teacher training techniques, physics and mathematics for lower secondary education and KEGA project No. 021UKF4/2014: Real remote experiments in the school practice and project ESF - ITMS 26110230096 Innovation of Study Programmes at Faculty of Education of Constantine the Philosopher University in Nitra for Improving Quality of Education Process.

\section{References}

Blažej, M. (2005). Technická pripravenost’ žiakov ZŠ pre štúdium na stredných odborných školách (Rigorous thesis), Nitra: Pedagogická fakulta Univerzity Konštantína Filozofa v Nitre.

Ďuriš, M., (2013). Vzdelávací štandard vyučovacieho predmetu Technika (Pracovné vyučovanie), tematické okruhy v 7.-9. ročníku ZŠ. Technika a vzdelávanie (pp.15-18). In T. Kozík, J. Kuzma, M. Kožuchová, M. Vargová, J. Pavelka, D. Lukáčová, \& M. Duriš. Zmeny a perspektivy technického Vzdelávania vo vzdelávacej oblasti Človek a svet práce. Technika a vzdelávanie, 2(2), 3-18. Banská Bystrica: Vydavatel'stvo UMB v Banskej Bystrici - Belianum.

Government Manifesto of the SR, 2012 (Programové vyhlásenie vlády SR. 2012). Retrieved from 


\section{Acta Technologica Dubnicae \\ volume 5, 2015, issue 3}

http://www.minedu.sk/index.php?lang=sk\&rootId=6596

Handlovská, I. (2011). Návrh vyučovacej hodiny na tému práca s drevom pre školy bez dielní. In G. Bánesz (ed.), Vzájomná informovanost'. Cesta $k$ efektívnemu rozvoju vedecko-pedagogickej činnosti (pp. 28-33). Nitra: UKF PF Nitra, Katedra techniky a informačných technológií.

http://www.statpedu.sk/files/documents/inovovany_statny_vzdelavaci_program/ zs/2_stupen/clovek_a_svet_\%20prace/technika_nsv_2014.pdf.

Kozík, T. (2013a). Predmetová komisia „Človek a svet práce“ - ciele a úlohy. Technika a vzdelávanie (pp. 3-6). In T. Kozík, J. Kuzma, M. Kožuchová, M. Vargová, J. Pavelka, D. Lukáčová, \& M. Duriš. Zmeny a perspektívy technického Vzdelávania vo vzdelávacej oblasti Človek a svet práce. Technika a vzdelávanie, 2(2), 3-18. Banská Bystrica: Vydavatel'stvo UMB v Banskej Bystrici - Belianum.

Kozík, T. (2013b). Output from the Commission of the Subject Man and the World of Work (Internal material).

Kozík, T., Pavelka, J., Kožuchová, M., Ďuriš, M., Lukáčová, D., Škodová, M., Kuzma, J., \& Špičan, P. (2013). Analýza a zdôvodnenie revízie vzdelávacej oblasti Človek a svet práce. Učitel'ské noviny, 60, 25-27.

Kozík, T., Handlovská, I. (2011a). Poznámka k tvorivosti v technickom vzdelávaní. Edukacja - Technika - Informatyka: Wybrane problemy edukacji technicznej i zawodowej, 3(2), 15-22.

Kozík, T., \& Handlovská, I. (2011b). The Reduction of Interest Among Elementary Students in the Field of Technical Education. International Journal of Engineering Pedagogy, 1(3), 9-12.

Kožuchová, M., \& Vargová, M. (2013). Pripravované zmeny v štátnom vzdelávacom programe na primárnom stupni z pohl'adu vzdelávacej oblasti Človek a svet práce. Technika a vzdelávanie (pp. 8-10). In T. Kozík, J. Kuzma, M. Kožuchová, M. Vargová, J. Pavelka, D. Lukáčová, \& M. Ďuriš. Zmeny a perspektívy technického Vzdelávania vo vzdelávacej oblasti Človek a svet práce. Technika a vzdelávanie, 2(2), 3-18. Banská Bystrica: Vydavatel'stvo UMB v Banskej Bystrici - Belianum.

Lukáčová, D. (2013). Vzdelávací štandard vyučovacieho predmetu Technika (Pracovné vyučovanie), tematické okruhy v 5. - 6. ročníku ZŠ, Technika a vzdelávanie (pp. 14-15). In T. Kozík, J. Kuzma, M. Kožuchová, M. Vargová, J. Pavelka, D. Lukáčová, \& M. Duriš. Zmeny a perspektívy technického Vzdelávania vo vzdelávacej oblasti Človek a svet práce. Technika a vzdelávanie, 2(2), 3-18. Banská Bystrica: Vydavatel'stvo UMB v Banskej Bystrici - Belianum.

Lukáčová, D., \& Bánesz, G. (2007). Premeny technického vzdelávania. Nitra: PF UKF v Nitre.

Pavelka, J. (2013). Návrh vzdelávacieho štandardu techniky pre nižší stupeň stredného vzdelávania $\mathrm{v}$ SR. Technika a vzdelávanie (pp. 11-14) In $\mathrm{T}$. Kozík, J. Kuzma, M. Kožuchová, M. Vargová, J. Pavelka, D. Lukáčová, \& 


\section{Acta Technologica Dubnicae \\ volume 5, 2015, issue 3}

M. Duriš. Zmeny a perspektívy technického Vzdelávania vo vzdelávacej oblasti Človek a svet práce. Technika a vzdelávanie, 2(2), 3-18. Banská Bystrica: Vydavatel'stvo UMB v Banskej Bystrici - Belianum.

Principles for the establishment and operation of the central curriculum committee. (Zásady zriad’ovania a činnosti ústredných predmetových komisií). Retrieved from www.statpedu.sk

Turek, I. (2011). Globalizácia a jej vplyv na inováciu technického vzdelávania. Retrieved from http://www.pulib.sk/elpub2/FHPV/Pavelka1/19.pdf www.minedu.sk 